\title{
Fractions of carbohydrates and of nitrogenous compounds of tropical grasses at different cutting ages ${ }^{1}$
}

\section{Patrícia Regina de Souza Siqueira Campos ${ }^{2}$, José Fernando Coelho da Silva ${ }^{3}$, Hernán Maldonado Vásquez ${ }^{3}$, Andréa Vittori ${ }^{4}$, Martinho de Almeida e Silva ${ }^{5}$}

\author{
1 Pesquisa parcialmente financiada pela FAPERJ. \\ 2 Doutoranda - LZNA-CCTA-Universidade Estadual do Norte Fluminense. \\ ${ }^{3}$ LZNA-CCTA-Universidade Estadual do Norte Fluminense. Pesquisador do CNPq. \\ ${ }^{4}$ Faculdade Filadélfia - Ribeirão Preto - SP. \\ 5 Universidade Federal de Minas Gerais. Pesquisador do CNPq.
}

\begin{abstract}
It was evaluated by the Cornell System carbohidrates fractions and nitrogenous compounds of the following grasses at the cutting ages of 14, 28, 42, and 56 days: nilo grass (Acroceras macrum), angola grass (Brachiaria purpurascens), aleman grass (Echinochloa polystachya), limpo grass (Hemarthria altíssima), setaria grass (Setaria anceps), tanner grass (Brachiaria arrecta), and tifton-85 grass (Cynodon spp). The experiment was carried out in a complete randomized block design, in a split plot arrangement in a way that the grasses were evaluated in the plots and the ages of cut in the split-plots. The age of cutting had an effect on the composition of the studied grasses. In most of the grasses, total carbohydrate levels, non-fibrous carbohydrates and $A+B_{1}$ fraction carbohydrates increased linearly according to the age of cutting. The potentially degradable fraction of carbohydrates (fraction $\mathrm{B}_{2}$ ) showed a quadratic behavior according to the cutting ages for all grasses. The $\mathrm{C}$ fraction of the carbohydrates in tifton-85 grass linearly increased with the age but it did not increase significantly for the other grasses. In setaria grass, the intermediate levels of $B_{2}$ and $B_{3}$ nitrogenous fractions were high, which might represent a potential source of protein for ruminal degradation and for the small intestine. Except for setaria grass, all studied grasses show similar values of the $A, B_{1}, B_{2}$ and $B_{3}$ nitrogenous fractions.
\end{abstract}

Key Words: chemical composition, Cornell system, forage, neutral detergent fiber, protein

\section{Fracionamento de carboidratos e compostos nitrogenados de gramíneas tropicais em diferentes idades de corte}

\begin{abstract}
RESUMO - Avaliaram-se pelo Sistema Cornell as frações de carboidratos e os compostos nitrogenados dos capins acroceres (Acroceras macrum), angola, (Brachiaria purpurascens), canarana (Echinochloa polystachya), hemarthria (Hemarthria altíssima), setária (Setaria anceps), tanner grass (Brachiaria arrecta) e tifton 85 (Cynodon spp) nas idades de corte de 14, 28, 42 e 56 dias. O experimento foi conduzido em blocos ao acaso em esquema de parcelas subdivididas de modo que as gramíneas foram avaliadas nas parcelas e as idades de corte, nas subparcelas. Houve efeito da idade de corte na composição dos carboidratos das gramíneas estudadas. Na maioria das gramíneas, os teores de carboidratos totais, carboidratos não-fibrosos e da fração $A+B_{1}$ aumentaram linearmente conforme a idade de corte. A fração potencialmente degradável dos carboidratos (fração $\mathrm{B}_{2}$ ) apresentou um comportamento quadrático em função da idade, para todas gramíneas. A fração C dos carboidratos do capim-tifton 85 apresentou aumento de forma linear com a idade, mas não aumentou de forma significativa para as demais gramíneas. No capim-setária, os teores médios das frações nitrogenadas $\mathrm{B}_{2}$ e $\mathrm{B}_{3}$ foram elevados, o que pode representar um bom aporte protéico para degradação ruminal e para o intestino delgado. Todas as gramíneas avaliadas, à exceção do capim-setária, apresentam valores similares das frações nitrogenadas $A, B_{1}, B_{2}$ e $B_{3}$.
\end{abstract}

Palavras-chave: composição química, fibra detergente neutro, forrageira, proteína, sistema Cornell

\section{Introduction}

The quality of the grass forage used in animal feeding is measured by its nutritional value. Recently, in addition to the values of chemical composition, it has been used the proportions of the fractions potentially digestible of carbohydrates and the nitrogenous compounds (Hall, 2007).

Researches have been done in order to characterize the foods based on their composition and to know the interactions between levels of food intake and the profile of 
absorbed nutrients, as well as the interactions of the flow of nutrients in the duodenum and the diet consumption (Gill et al., 1989). The accurate estimate of the fractions in the foods has been used to supply databases of tropical foods and consequently to balance ruminant diets.

The systems of nutritional requirements based on metabolizable energy (AFRC, 1993), total digestible nutrients (NRC, 2001) and CNCPS (Cornell Net Carbohydrate and Protein System, Sniffen et al., 1992) have practical application in balancing and evaluating of diets for ruminants. The Cornell system is based on the availability of energy coming from carbohydrates and from nitrogenous compounds for maximization of the microbial growth in the rumen.

CNCPS considers that foods are composed by carbohydrates, crude protein, fat, ash and water. Crude protein involves three categories: non-protein nitrogenous compounds (NPNC), known as the A fraction; true protein, which is B fraction; and the protein linked to the other components, which is $\mathrm{C}$ fraction, which represents the acid detergent insoluble protein (ADIP) not available for the digestion (Fox et al., 2004).

The $\mathrm{B}$ fraction of the proteins is subdivided in three parts, according to the rumen degradability: $B_{1}, B_{2}$ and $B_{3}$ for fast, moderate, and slow rate of rumen degradation, respectively.

Carbohydrates are fractionated into sugars (A fraction), pectic substances (fraction $\mathrm{B}_{1}$ ), potentially degraded structural carbohydrates ( $\mathrm{B}_{2}$ fraction), and the undigested fiber that is calculated by the lignin level multiplied by the factor 2.4 (C fraction).

It is important to consider that the adequate ages of cutting allows the rational exploration of the productive potential and the nutritional value of the plant. Plant tissues became lignified as age increases, changing the composition of the cellular wall of the vegetables (Akin \& Burdick, 1975).

The objective of the present research was to evaluate the composition of the carbohydrate fractions and the nitrogenous compounds of aleman grass, nilo grass, tanner grass, angola grass, limpo grass, setaria grass, and tifton85 grass under different cutting ages.

\section{Material and Methods}

The experiment was carried out in the Laboratório de Zootecnia e Produção Animal of the Universidade Estadual do Norte Fluminense - Rio de Janeiro, Brazil. Aleman grass (Echinochloa polystachya, Hitch), nilo grass (Acroceras macrum, Stapf.), tanner grass (Brachiaria arrecta (Hack. former T. Durand \& Schinz) Stent.), angola grass (Brachiaria purpurascens, Henr.), limpo grass (Hemarthria aliíssima, Swamp Couch), setaria grass (Setaria anceps, Stapf. former Massey) and tifton-85 grass (Cynodon spp) were grown in an experimental area that was divided in three blocks of $35 \times 2.5 \mathrm{~m}\left(87.5 \mathrm{~m}^{2} /\right.$ block$)$. Each block contained seven plots measuring $5 \times 2.5 \mathrm{~m}$ (total of $12.5 \mathrm{~m}^{2}$ ), spaced by $1.5 \mathrm{~m}$ from each other. In each plot, four areas of $1.25 \times 2.50 \mathrm{~m}$ were delimited (total $3.125 \mathrm{~m}^{2}$ ), for each cutting age, with a central area of $0.75 \times 1.5\left(1.125 \mathrm{~m}^{2}\right)$.

The cuts were performed $10 \mathrm{~cm}$ above the soil surface, at the ages of 14, 2842 and 56 days of regrowth. Grass samples were dried in forced ventilation oven at $55^{\circ} \mathrm{C}$ for 72 hours and grounded into 1 -mm particle size for determination of the chemical composition. The analyses of the dry matter (DM), crude protein (CP), mineral matter (MM), ether extract (EE), lignin (LIG), neutral detergent fiber (NDF), neutral detergent fiber corrected for ashes and protein (NDFap), acid detergent fiber (ADF), neutral detergent insoluble nitrogen (NDIN), acid detergent insoluble nitrogen (ADIN) were performed according to the methodology described by Silva \& Queiroz (2004). The values of neutral detergent insoluble protein (NDIP) and acid detergent insoluble protein (ADIP) were calculated by multiplying the factor 6.25 by the levels of NIDN and ADIN of the sample, respectively (Table 1 ).

The total carbohydrates (TCH) and the $\mathrm{A}+\mathrm{B}_{1}, \mathrm{~B}_{2}$ and $\mathrm{C}$ fractions were calculated as described by Sniffen et al. (1992) as it follows: $\left.\mathrm{TCH}_{(\% \mathrm{DM})}=100-\mathrm{CP}_{(\% \mathrm{DM})}-\mathrm{EE}_{(\% \mathrm{DM})}\right)^{-}$ $\mathrm{MM}_{(\% \mathrm{DM})} ; \mathrm{B}_{2}=100 *\left(\mathrm{NDF}_{(\% \mathrm{DM})}-\mathrm{NDIP}_{(\% \mathrm{CP})} * 0.01\right.$

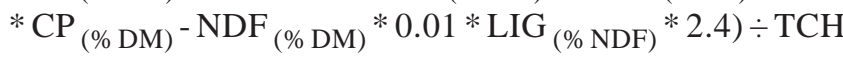
$(\% \mathrm{DM}) ; \mathrm{A}+\mathrm{B}_{1}=100-\left(\mathrm{C}+\mathrm{B}_{2}\right) ; \mathrm{C}=(100 * \mathrm{NDF}(\% \mathrm{DM}) *$ $\left.0.01 * \mathrm{LIG}_{(\% \mathrm{NDF})} * 2.4\right) \div \mathrm{TCH}(\% \mathrm{DM})$.

The $\mathrm{A}+\mathrm{B}_{1}$ fraction, considered as the non structural carbohydrates (NSC) was also obtained as: NSC $=\mathrm{OM}$ $(\mathrm{CP}+\mathrm{EE}+\mathrm{NDFap})$ and organic matter $(\mathrm{OM})=\mathrm{DM}-\mathrm{MM}$.

The nitrogenous compounds of the grasses were divided into $\mathrm{A}$ fraction (non protein nitrogen), $\mathrm{B}_{1}$ fraction (peptides and polypeptides), $\mathrm{B}_{2}$ fraction (cytoplasmatic proteins), $\mathrm{B}_{3}$ fraction (neutral detergent insoluble proteins) and $C$ fraction (acid detergent insoluble proteins), according to Krishnamoorthy et al. (1983); Licitra et al. (1996) and Malafaia \& Vieira (1997).

The statistical analysis was carried out according to a complete randomized block design, in a split plot arrangement with three replications, so that the grasses were allocated in the main plots and the cutting ages in the split plots. The results were interpreted statistically through variance analysis. The means of the grasses were compared by the Tukey's test and the effects of cutting 
Table 1 - Chemical composition of the grasses at different cutting ages, expressed on dry matter basis

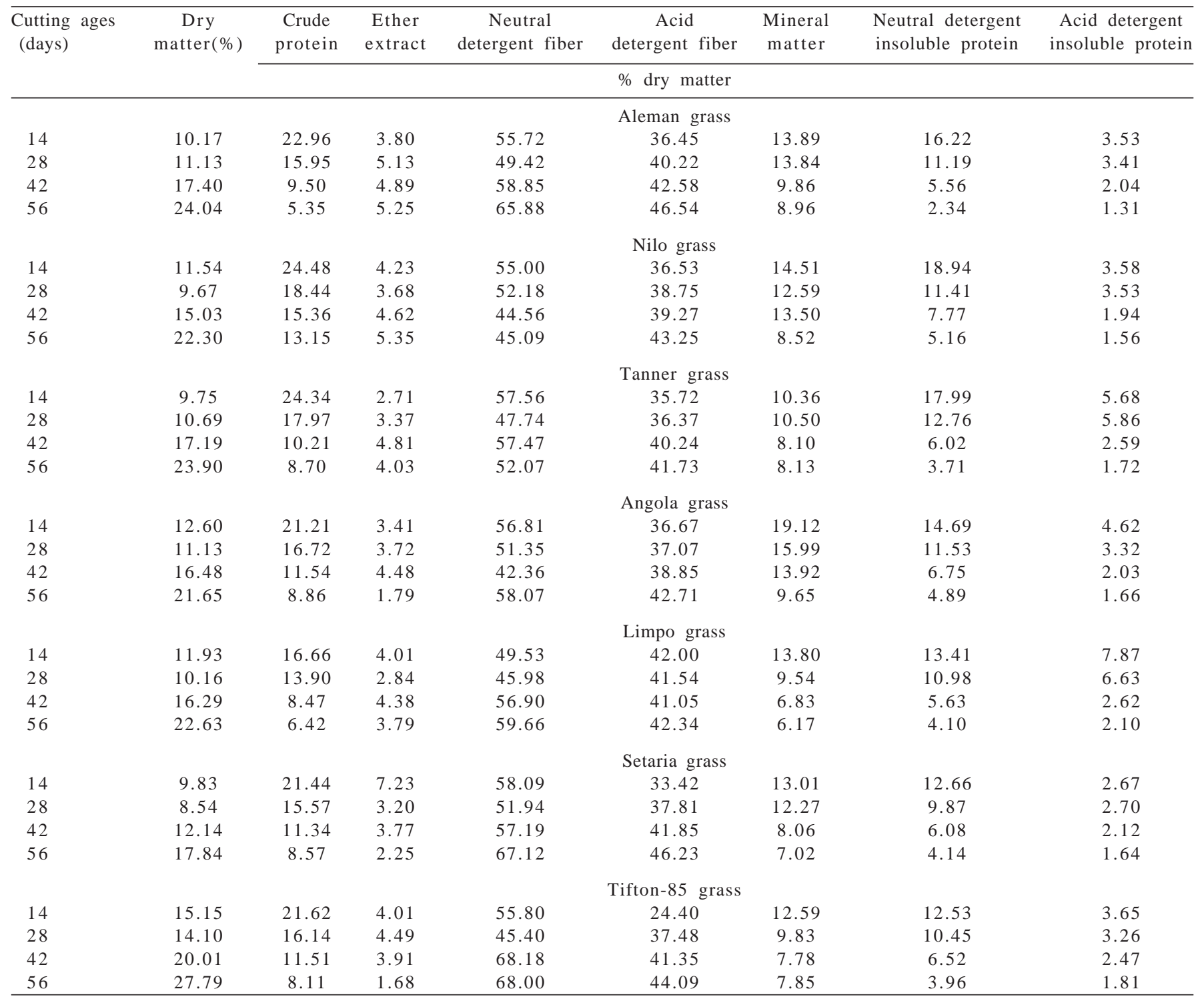

ages were evaluated by regression analysis according to SAEG(UFV, 2000).

For the models of a same variable with significant coefficients, the selection was based on the polynomial model of higher degree. The variables were analyzed based in the following statiscal model: $\mathrm{Y}_{\mathrm{ijk}}=\mu+\rho_{\mathrm{i}}+\alpha_{\mathrm{j}}+\gamma_{\mathrm{ij}}+\beta_{\mathrm{k}}$ $+(\alpha \beta a b)_{j k}+\varepsilon_{i j k}$, in which: $Y_{i j k}$ is the variable of the block $\mathrm{i}(\mathrm{i}=1,2,3)$, relating to the grass $\mathrm{j}$ in the parcel $(\mathrm{j}=1,2,3$, $4,5,6,7)$ and to the cutting age $k$ is allocated in the sub parcel $(\mathrm{k}=1,2,3,4) ; \mu=$ general average; $\rho_{\mathrm{i}}=$ effect of the block $\mathrm{i}$; $\alpha_{j}=$ effect of grasses $\mathrm{j}$ in the parcel; $\gamma_{\mathrm{ij}}=$ random error of the parcel; $\beta_{\mathrm{k}}=$ effect of the cutting age $\mathrm{k}$ in the sub parcel; $(\alpha \beta)_{\mathrm{jk}}=$ effect of the interaction between grass $\mathrm{j}$ and the cutting age $\mathrm{k} ; \varepsilon_{\mathrm{ijk}}=$ random error of the sub parcel, supposing NID $~\left(0, \sigma^{2}\right)$.

\section{Results and Discussion}

The levels of total carbohydrates were influenced $(\mathrm{P}<0.01)$ by the species of the forage and the cutting age. The level of total carbohydrates of the setaria grass showed a quadratic behavior as a function of the cutting age, while the other grasses showed linear increase. The maximum level of total carbohydrates of the setaria grass was estimated on the $76^{\text {th }}$ day of age, equal to $84.85 \%$. Daily increases in the levels of total carbohydrates of nilo grass, tanner grass, limpo grass, tifton-85 grass, aleman grass and angola grass were $0.36 ; 0.42 ; 0.44 ; 0.49 ; 0.53$ and 0.55 percent units, respectively.

Usually ruminant diets are based on carbohydrates, for this reason it is nutritionally important to know the fractions 
that compose the total carbohydrates present in the foods. For this comparison, the levels of the carbohydrate fractions were expressed in percentage of the total carbohydrates.

Limpo grass presented high levels of total carbohydrates for all cutting ages. The means of each grass, in each cutting age (Table 2) showed that the largest level of total carbohydrates was found in limpo grass when compared to the nilo grass and angola grass on the $14^{\text {th }}$ day. However, on the $28^{\text {th }}$ day, limpo grass showed higher levels of total carbohydrates than nilo grass, aleman grass and angola grass. At the cutting age of 42 days, the levels of total carbohydrates of the limpo grass was higher than the levels of nilo grass. Nevertheless, on the $56^{\text {th }}$ day, the levels of total carbohydrates of limpo grass, in tifton-85 grass and in the setaria grass were larger than those of the nilo grass.

The values for limpo grass were similar to those found by Lacerda et al. (2004) in a study done in a coastal slope area in Rio de Janeiro,in which the levels of total carbohydrates varied from $78.88 \%$ to $83.97 \%$ of dry matter. In a similar way, Henriques et al. (2007a), when studying nilo grass, angola grass, limpo grass, and setaria grass found similar average values for total carbohydrates at the cutting ages of 28, 42 and 56 days.

The estimates of the level of total carbohydrates of tifton-85 grass calculated using the regression equation at the age of 60 days obtained the value of $84.78 \%$. This is higher than the observed by Malafaia et al. (1996) at the same cutting age (79.63\%).

In the fractioning of the carbohydrates according to the Cornell system, the non-structural carbohydrates (NSC) include $\mathrm{A}$ fraction (sugars) and $\mathrm{B}_{1}$ fraction (starch and soluble fibrous compounds) (Sniffen et al., 1992).

In this study, the levels of non-structural carbohydrates differed among the grasses $(\mathrm{P}<0.05)$ and among cutting ages $(\mathrm{P}<0.01)$, but the Tukey's test did not detect effect of the cutting age on the levels of non-structural carbohydrates in aleman grass, limpo grass and tifton-85 grass (Table 3 ).
The maximum level of non structural carbohydrates of angola and setaria grasses was estimated to occur on the $42^{\text {nd }}$ and $39^{\text {th }}$ days and to be 26.54 and $21.25 \%$, respectively. The daily increases of non-structural carbohydrates of the nilo grass and tanner grass were of 0.39 and 0.28 percent units, respectively.

The means of the grasses in each cutting age (Table 3) show that only on the $56^{\text {th }}$ day they differed $(\mathrm{P}<0.05)$ on the level of non-structural carbohydrates, with the nilo grass presenting the highest level, and the aleman grass, the lowest value among the grasses.

From all forages evaluated, the percentage of nonstructural carbohydrates, on average, represents only a small part of the total carbohydrates. Vieira et al. (2000) evaluated the level of non-structural carbohydrates in native pasture in the east part of Minas Gerais State (Brazil) and they found means of non-structural carbohydrates ranging from $12.5 \%$ to $15 \%$, in the dry and rainy seasons of the year, respectively.

Tropical grasses, in general, have relatively low levels of non-structural carbohydrates because they accumulate these carbohydrates in the roots and in the base of the stem, and this process usually happens in an inverse proportion to the leaves production (Wilson, 1975). Quantitatively, starch is the most important non-structural carbohydrates, and it appears in reduced levels in the aerial part of the tropical forages. Such grasses present thicker cellular wall, with high proportions of the following tissues: xylem, esclerenchyma, and parenchymatic sheath of the vascular bunches (Akin, 1989).

The levels of the $A+B_{1}$ fraction calculated by the difference NSC $=100-\left(B_{2}+C\right)$ showed a behavior similar to that calculated using the formula of NSC $=\mathrm{OM}-(\mathrm{CP}+\mathrm{EE}$ + NDFap). There was a difference among cutting ages $(\mathrm{P}<0.01)$ in the levels of the $\mathrm{A}+\mathrm{B}_{1}$ fraction and a significant interaction among grasses and cutting age $(\mathrm{P}<0.05)$. The levels of the $\mathrm{A}+\mathrm{B}_{1}$ fraction of the nilo grass and tanner grass presented

Table 2 - Levels of total carbohydrates (TCH, \% DM) of the grasses and their respectives regression equations, in relation to the cutting age ( $x$, in days)

\begin{tabular}{|c|c|c|c|c|c|c|c|}
\hline \multirow[t]{2}{*}{ Grass } & \multicolumn{4}{|c|}{ Cutting age (days) } & \multirow{2}{*}{\multicolumn{2}{|c|}{ Equation $^{1}$}} & \multirow[t]{2}{*}{$\mathrm{r}^{2}$} \\
\hline & $14 *$ & $28 *$ & $42 * *$ & $56 *$ & & & \\
\hline Aleman grass & $59.34 \mathrm{ab}$ & $65.08 \mathrm{~b}$ & $75.75 a b$ & $80.44 \mathrm{ab}$ & 70.15 & $\hat{y}=51.66+0.53 x^{* *}$ & 0.91 \\
\hline Nilo grass & $56.78 b$ & $65.29 b$ & $66.52 c$ & $72.98 b$ & 65.39 & $\hat{y}=52.93+0.36 x^{* *}$ & 0.62 \\
\hline Tanner grass & $62.60 \mathrm{ab}$ & $68.16 \mathrm{ab}$ & $76.87 \mathrm{ab}$ & 79.13ab & 71.69 & $\hat{y}=57.11+0.42 x^{* *}$ & 0.86 \\
\hline Angola grass & $56.27 \mathrm{~b}$ & $63.57 b$ & $70.05 \mathrm{bc}$ & $79.70 \mathrm{ab}$ & 67.40 & $\hat{y}=48.20+0.55 x^{* *}$ & 0.86 \\
\hline Limpo grass & $65.53 a$ & $73.73 a$ & $80.32 \mathrm{a}$ & $83.63 a$ & 75.80 & $\hat{y}=60.58+0.44 x^{* *}$ & 0.92 \\
\hline Setaria grass & $58.32 \mathrm{ab}$ & $68.96 a b$ & $76.82 \mathrm{ab}$ & $82.16 \mathrm{a}$ & 71.56 & $\hat{y}=45.09+1.04 x^{* *}-0.0068 x^{2 *}$ & 0.97 \\
\hline Tifton 85 grass & $61.78 \mathrm{ab}$ & $69.54 \mathrm{ab}$ & $76.80 \mathrm{ab}$ & $82.35 a$ & 72.62 & $\hat{y}=55.38+0.49 x^{* *}$ & 0.98 \\
\hline
\end{tabular}

Means followed by the same letter, in the same column do not differ by Tukey's test.

Significant at $1 \%(* *)$ and $5 \%(*)$ of probability.

${ }^{1} \hat{y}$ in \% DM. 
Table 3 - Levels of carbohydrate fractions of the grasses and the respective regression equations as a function of cutting ages (x, in days)

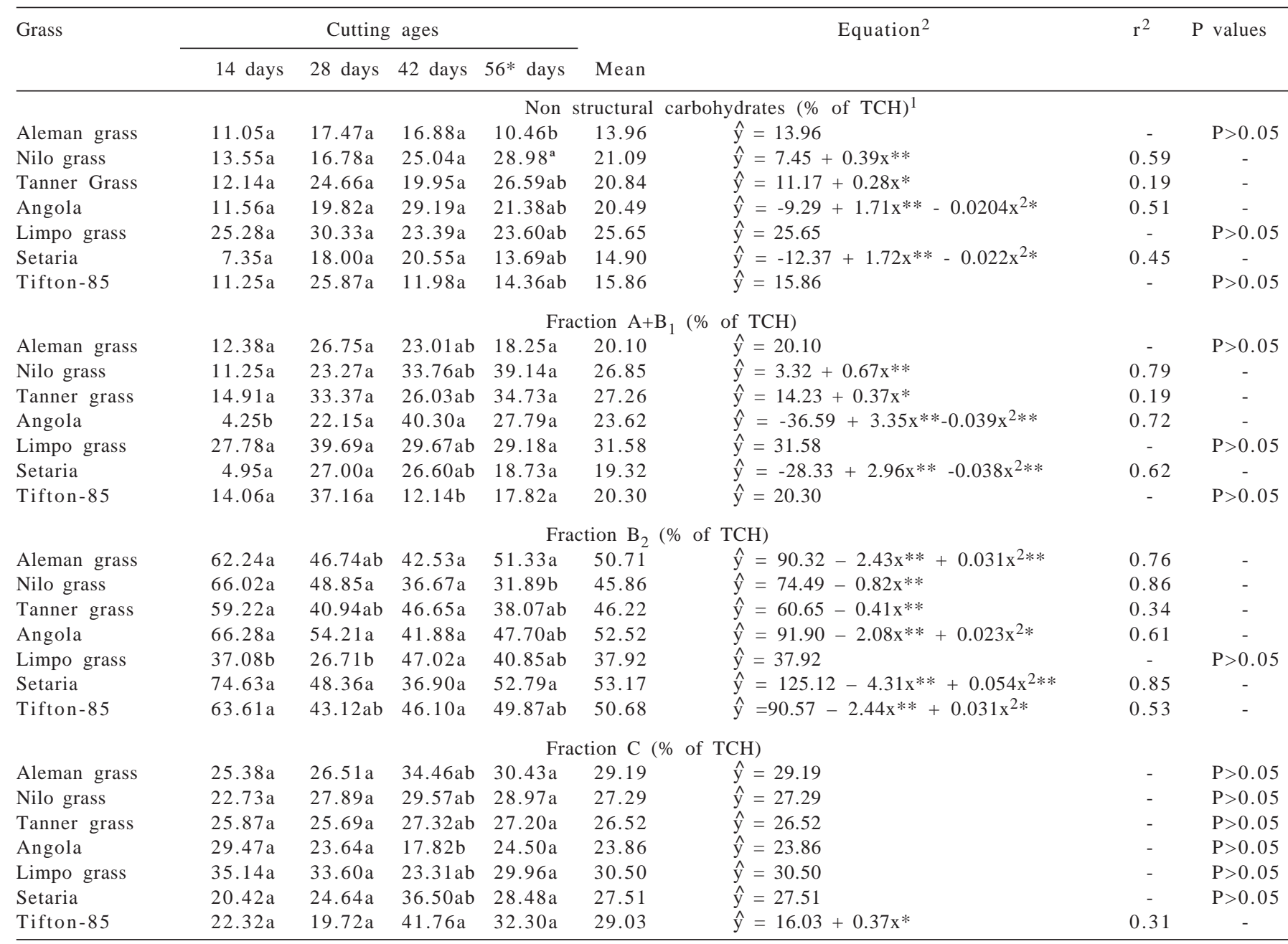

${ }^{1}$ Non structural carbohydrate $=\mathrm{OM}-(\mathrm{CP}+\mathrm{EE}+\mathrm{NDFap})$.

Means followed by the same letter, in the same column do not differ by Tukey's test.

Significant at $1 \%(* *)$ and $5 \%(*)$ of probability.

${ }^{2} \hat{y}$ in \% DM.

$\mathrm{TCH}=$ Total carbohidrates

a linear increase as a function of the cutting age while for the angola and setaria grasses they presented a quadratic behavior. The equations of linear and quadratic regression of the aleman grass, limpo grass and tifton-85 grass were not significant (Table 4); the same was true for the non structural carbohydrates (Table 3).

On the $14^{\text {th }}$ day, the level of the $A+B_{1}$ fraction of the angola grass was smaller than the others grasses, while on the $42^{\text {nd }}$ day, it was larger than that of tifton-85.

The values calculated for the $\mathrm{A}+\mathrm{B} 1$ fraction using the equation $\mathrm{A}+\mathrm{B} 1=100-(\mathrm{C}+\mathrm{B} 2)$ seems to overestimate, on average, the levels of NSC, although the tendency of the regression equations, in function of the cutting age, have been similar.

The non-structural carbohydrates $\left(A+B_{1}\right.$ fraction) are sources of quickly available energy, because these carbohydrates are rapidly digested by ruminal microorganisms. $\mathrm{B}_{2}$ fraction includes carbohydrates of slow degradation, which is the potentially degradable neutral detergent fiber fraction (Sniffen et al., 1992).

B2 fraction (\% TCH) differed among grasses and cutting ages and there was interaction between grasses and cutting age $(\mathrm{P}<0.01)$. The levels of this fraction in the aleman grass, angola grass, setaria grass and tifton-85 grass showed a quadratic behavior in function of the cutting age, while the nilo grass and tanner grass presented a linear decrease. The equations for linear and quadratic regression of limpo grass were not significant (Table 3).

The daily decreases of the $\mathrm{B}_{2}$ fraction of the nilo grass and tanner grass were of 0.82 and 0.41 percent units, respectively, and the limpo grass showed an average value of $37.92 \%$. In general, as the physiological age of the plant advanced, an increase of cell wall constituents was found with a consequent reduction in the levels of non-structural 
carbohydrates (Van Soest, 1994). The increase in the proportion of the $\mathrm{B}_{2}$ fraction is correlated with the level of neutral detergent fiber in the forage that supplies energy in a relatively slow rate causing an impact on the efficiency of microbial synthesis, consequently negatively interfering in the animal behavior.

On the $14^{\text {th }}$ day, limpo grass presented the lowest level of $\mathrm{B}_{2}$ fraction (\% TCH). The levels of the $\mathrm{B}_{2}$ fraction of tifton- 85 grass at 28,42 and 56 days of age (43.12; 46.10 and $49.87 \%$, respectively) were smaller than those found by Ribeiro et al. (1998), for tifton-85 hay at the same cutting ages (87.45; 88.54 and 85.93\%, respectively), and than those related by Malafaia et al. (1996) for tifton- 85 grass at 60 days of age (74.38\%), estimated by the regression equation obtained for this grass (Table 3 ) at the same cutting age (55.77\%).

The $\mathrm{C}$ fraction corresponds to the non-degradable percentage of the neutral detergent fiber (Sniffen et al., 1992). The increase of this fraction results in a larger effect in the ruminal repletion and a decrease of the energy availability due to indigestibility along the digestive tract (Jung \& Allen, 1995).

It should be noted that the digestibility of the fiber is not affected by the fibrous content, but rather by the nondigestible fraction, the digestion rate and passage rate. Therefore, it is interesting to reduce the non-digestible fraction of the cell wall of forages to provide animals sources of a good rumen degradability fiber (Jung \& Allen, 1995).

For the carbohydrate $\mathrm{C}$ fraction, which is considered unavailable in the rumen and intestines (Sniffen et al., 1992; Mertens, 1993), it was found, in this study, an interaction among grasses and cutting ages $(\mathrm{P}<0.05)$. The level of the $\mathrm{C}$ fraction of the tifton-85 grass showed a linear increase as a function of the cutting ages while the regression equations for the others grasses were not significant (Table 3).

The daily increment of the $\mathrm{C}$ fraction of the tifton-85 was of 0.37 percent units. Only on the $42^{\text {nd }}$ day there was difference among the levels of the $\mathrm{C}$ fraction of the grasses. Tifton-85 presented larger level than angola grass. Ribeiro et al. (1998) found levels of the $C$ fraction of tifton-85 hay at the ages of 28, 42 and 56 days at the values of $8.01 ; 9.43$ and $10.79 \%$, respectively, which were smaller than the values related in the present work, for the same ages (19.72; 41.76 and 32.30\%); however Malafaia et al. (1996) observed higher level for tifton-85, on the $60^{\text {th }}$ day of age (38.23\%) compared with the estimated value by the regression equation from this work.

Levels of the $\mathrm{C}$ fraction of the total carbohydrates ranged from 30.50 to $23.86 \%$. This fraction is composed by the unavailable cell wall, or non-digestible fiber, which is not used by ruminal microorganisms. In fact, it is undesirable to have high values because as plant age advances, the leaf area increases. In general, studies done on the morphogenic characteristics of these grasses show changes in the proportions of the vegetable tissues, explained by the thickness of the cell wall. Rosa et al. (1999), when studying angola grass, identified significant increases in the leaf:stem relationship, which were $0.22 ; 0.33$; and 0.59 at the cutting ages of 14, 28 and 56 days, respectively.

Although the tanner grass showed low levels of $\mathrm{C}$ fraction, what would be an attractive characteristic, nutrionally speaking, its utilization has not been indicated because of a suspicion of intoxication in bovine. Besides, this is the favorite grass of thumbtack-grasses (Blissus antillus) in the states of Minas Gerais, Mato Grosso do Sul and Rio de Janeiro, because its vegetative propagation aids in the spread of the thumbtack (Tokarnia et al., 1997; Valério, 2000).

Gonçalves et al. (2003) evaluated the fractions of carbohydrates of Tifton 85 hay at the cutting ages of 28, 42, 63 and 84 days and they observed increases in the $\mathrm{C}$ fraction as age advanced, which ranged from 10.9 to $14.3 \%$. This is due to an increased lignin fraction instead of the other fractions.

Therefore, studies that describes the kinetic parameters of degradation of these grasses are pertinent for a better characterization of their nutritional value. And the accuracy in the prediction of the animal requirements by CNCPS depends on the accuracy on the description of the feed composition.

The levels of the A fraction as a percentage of the crude protein were influenced by the forage species and cutting age $(\mathrm{P}<0.01)$. And in aleman grass, angola grass, limpo grass and tifton-85 grass, the levels of the A fraction showed a quadratic behavior in relation to the cutting age, while the nilo grass presented linear increases. The regression equations for tanner grass and setaria grass were not significant (Table 4).

The minimum levels of the A fraction of crude protein of the aleman grass, angola grass, limpo grass and tifton85 grass were estimated to occur on the $39^{\text {th }}$ and $40^{\text {th }}$, days of age and they were 18.49; 18.53; 4.45 and 19.95\%, respectively. The daily linear increment of the A fraction of the nilo grass was of 0.24 percent units.

Ribeiro et al. (1998) reported levels for the A fraction of tifton- 85 hay, on the $28^{\text {th }}, 42^{\text {nd }}$ and $56^{\text {th }}$ days, of 24.63 ; 25.13 and $35.53 \%$, respectively, which were larger than those observed in the present work for the tifton-85 grass at the same ages (20.82; 22.02 and 24.02\%, respectively). Malafaia et al. (1997) observed a level of 17.38\% for tifton- 
Table 4 - Levels of the A fraction (\% crude protein) of the grasses and the respective regression equations in relation to the cutting age (x, in days)

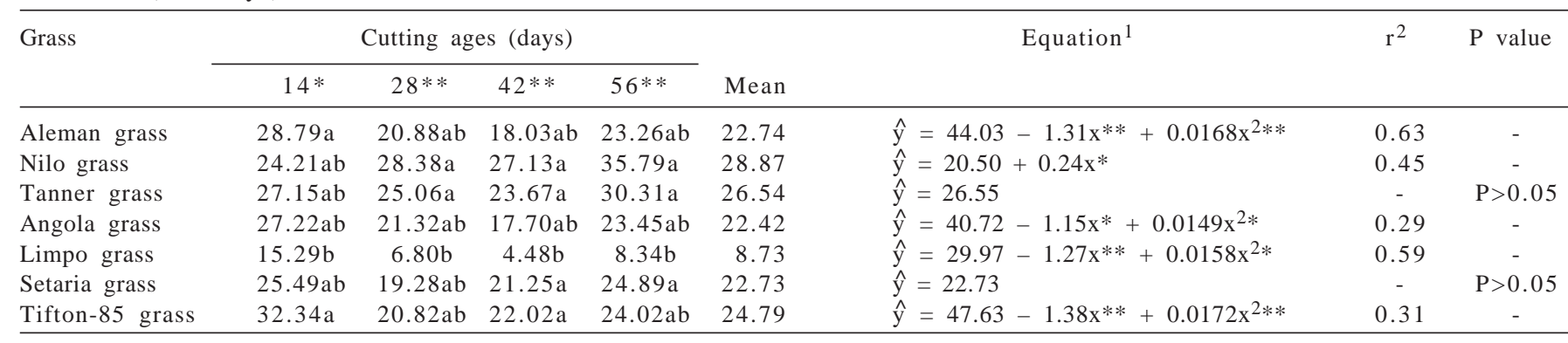

Means followed by the same letter, in the same column do not differ by Tukey's test.

Significant at $1 \%(* *)$ and $5 \%(*)$ of probability. ${ }^{1} \hat{y}$ in $\% \mathrm{DM}$.

85 , on the $60^{\text {th }}$ day of age, which was smaller than the values presented in this research, described in Table 4 (26.75\%).

Henriques et al. (2007b) observed reduced levels of nonprotein nitrogen at advanced age of harvest for angola grass, nilo grass, limpo grass and setaria grass. This tendency was not observed for the referred grasses in this study.

The level of the $B_{1}$ fraction of the nitrogenous compounds was only influenced by the cutting age $(\mathrm{P}<0.01)$. Aleman grass, tanner grass, angola grass, limpo grass and setria grass showed a linear increment in the level of the $B_{1}$ fraction of the nitrogenous compounds, depending on the cut. However the regression equations for the others grasses were not significant (Table 5). The daily increments of the $\mathrm{B}_{1}$ fraction in the crude protein of the setaria grass, tanner grass, angola grass, limpo grass and aleman grass were $0.11 ; 0.12 ; 0.14 ; 0.16$ and 0.22 percent units, respectively.

The levels of the $B_{1}$ fraction in the tifton- 85 on the $28^{\text {th }}$, $42^{\text {nd }}$ and $56^{\text {th }}$ days $(8.60 ; 6.51$ and $7.00 \%$, respectively), were larger than the observed by Ribeiro et al. (1998) in tifton-85 hay, at the same ages $(2.56 ; 2.72$ and $0.24 \%$, respectively) and by Malafaia et al (1997), for tifton-85 on the $60^{\text {th }}$ day $(2.54 \%)$.

The high proportions of the crude protein $A$ and $B_{1}$ fractions, with their high digestion rates, can cause larger

Table 5 - Levels of the fractions $\mathrm{B}_{1}, \mathrm{~B}_{2}$, and $\mathrm{B}_{3}(\% \mathrm{CP})$ of the grasses and the respective regression equations in relation to the cutting age ( $\mathrm{x}$, in days)

\begin{tabular}{|c|c|c|c|c|c|c|c|c|}
\hline \multirow[t]{2}{*}{ Grass } & \multicolumn{4}{|c|}{ Cutting ages (days) } & \multicolumn{2}{|r|}{ Equation $^{1}$} & \multirow[t]{2}{*}{$\mathrm{r}^{2}$} & \multirow[t]{2}{*}{$\mathrm{P}$ value } \\
\hline & 14 & 28 & 42 & 56 & \multicolumn{2}{|l|}{ Mean } & & \\
\hline \multicolumn{9}{|c|}{$\mathrm{B}^{1}$ fraction } \\
\hline Aleman grass & $0.59 a$ & $6.86 a$ & $8.98 a$ & $10.14 \mathrm{a}$ & 6.64 & $\hat{y}=-1.05+0.22 x^{* *}$ & 0.51 & - \\
\hline Nilo grass & $4.46 a$ & $5.61 \mathrm{a}$ & $5.54 \mathrm{a}$ & $6.98 a$ & 5.65 & $\hat{y}=5.65$ & - & $\mathrm{P}>0.05$ \\
\hline Tanner grass & $2.47 \mathrm{a}$ & $5.12 \mathrm{a}$ & $5.15 \mathrm{a}$ & $8.13 a$ & 5.22 & $\hat{y}=0.97+0.12 x^{*}$ & 0.32 & - \\
\hline Angola grass & $4.68 a$ & $8.04 \mathrm{a}$ & $8.88 a$ & $10.91 \mathrm{a}$ & 8.13 & $\hat{y}=3.25+0.14 x^{* *}$ & 0.68 & - \\
\hline Limpo grass & $3.81 \mathrm{a}$ & $9.46 \mathrm{a}$ & $8.68 \mathrm{a}$ & $11.73 \mathrm{a}$ & 8.42 & $\hat{y}=2.67+0.16 x^{* *}$ & 0.42 & - \\
\hline Setaria grass & $2.35 \mathrm{a}$ & $5.28 \mathrm{a}$ & $4.88 \mathrm{a}$ & $7.72 \mathrm{a}$ & 5.06 & $\hat{y}=1.13+0.11 x^{*}$ & 0.46 & - \\
\hline Tifton-85 grass & $4.13 \mathrm{a}$ & $8.60 \mathrm{a}$ & $6.51 \mathrm{a}$ & $7.00 \mathrm{a}$ & 6.56 & $\hat{y}=6.56$ & - & $\mathrm{P}>0.05$ \\
\hline \multicolumn{9}{|c|}{$\mathrm{B}_{2}$ fraction } \\
\hline Aleman grass & $1.60 \mathrm{a}$ & $2.66 \mathrm{a}$ & $14.45 \mathrm{a}$ & $22.77 \mathrm{a}$ & 10.37 & $\hat{y}=-8.46+0.54 x^{* *}$ & 0.84 & - \\
\hline Nilo grass & $0.00 \mathrm{~b}$ & $5.78 \mathrm{a}$ & $16.65 a$ & $18.01 \mathrm{a}$ & 10.11 & $\hat{y}=-6.12+0.46 x^{* *}$ & 0.68 & - \\
\hline Tanner grass & $1.80 \mathrm{a}$ & $1.03 a$ & $13.00 \mathrm{a}$ & $18.86 a$ & 8.67 & $\hat{y}=-7.11+0.45 x^{* *}$ & 0.71 & - \\
\hline Angola grass & $0.32 b$ & $1.98 \mathrm{a}$ & 14.63a & $12.50 \mathrm{a}$ & 7.36 & $\hat{y}=-4.94+0.35 x^{* *}$ & 0.47 & - \\
\hline Limpo grass & $3.44 \mathrm{a}$ & $5.97 \mathrm{a}$ & $20.24 \mathrm{a}$ & $15.88 \mathrm{a}$ & 11.38 & $\hat{y}=-1.52+0.37 x^{* *}$ & 0.55 & - \\
\hline Setaria grass & $13.24 \mathrm{a}$ & $11.78 \mathrm{a}$ & $19.42 \mathrm{a}$ & $18.52 \mathrm{a}$ & 15.74 & $\hat{y}=15.74$ & - & $\mathrm{P}>0.05$ \\
\hline Tifton-85 grass & $5.68 \mathrm{a}$ & $5.85 a$ & $14.35 a$ & $19.87 \mathrm{a}$ & 11.44 & $\hat{y}=-1.32+0.36 x^{* *}$ & 0.66 & - \\
\hline \multicolumn{9}{|c|}{$\mathrm{B}_{3}$ fraction } \\
\hline Aleman grass & $55.37 \mathrm{ab}$ & $48.75 a$ & $37.08 \mathrm{a}$ & $18.83 a$ & 40.01 & $\hat{y}=55.78+0.17 x^{n s}-0.0148 x^{2 *}$ & 0.91 & - \\
\hline Nilo grass & $62.78 \mathrm{a}$ & $42.57 \mathrm{ab}$ & $37.86 a$ & $27.31 \mathrm{a}$ & 42.63 & $\hat{y}=70.41-0.79 x^{* *}$ & 0.83 & - \\
\hline Tanner grass & 49.79abc & $39.52 \mathrm{ab}$ & $32.51 \mathrm{a}$ & $22.74 \mathrm{a}$ & 36.14 & $\hat{y}=58.18-0.63 x^{* *}$ & 0.64 & - \\
\hline Angola grass & 47.30abc & $49.05 a$ & $41.04 \mathrm{a}$ & $34.52 \mathrm{a}$ & 42.98 & $\hat{y}=54.56-0.33 x^{* *}$ & 0.38 & - \\
\hline Limpo grass & $33.37 c$ & $31.41 b$ & $35.64 a$ & $31.01 \mathrm{a}$ & 32.86 & $\hat{y}=32.86$ & - & $\mathrm{P}>0.05$ \\
\hline Setaria grass & 46.46abc & $46.28 \mathrm{ab}$ & $35.39 a$ & $29.40 \mathrm{a}$ & 39.38 & $\hat{y}=54.90-0.44 x^{* *}$ & 0.78 & - \\
\hline Tifton-85 grass & $41.04 \mathrm{bc}$ & $44.60 \mathrm{ab}$ & $35.3 a$ & $26.93 a$ & 36.97 & $\hat{y}=34.95+0.69 x^{n s}-0.0152 x^{2 *}$ & 0.73 & - \\
\hline
\end{tabular}

Means followed by the same letter, in the same column do not differ by Tukey's test. Significant at $1 \%(* *)$ and $5 \%(*)$ of probability and ns $=$ non significant $(\mathrm{P}>0.05)$. $1 \hat{y}$ in \% DM. 
losses of ammonia, when sources of fast degradation carbohydrates are not available in the rumen. It requires a good synchronism in the fermentation of proteins and carbohydrates, for efficient microbial synthesis in the rumen and consequent improvement in the animal performance (Nocek \& Russel, 1998). The crude protein fraction $B_{3}$, that may represent $1 / 3$ of the crude protein of the hays, approximately, and have lower digestion rate, consequently will result in larger escape to the intestines.

The level of the $\mathrm{B}_{2}$ fraction of the crude protein was only affected by the cutting age $(\mathrm{P}<0.01)$. All the grasses showed linear increase in the $\mathrm{B}_{2}$ fraction of the crude protein in function of the cutting age, except the setaria grass in which the linear and quadratic equations were not significant (Table 5).

The daily increases in the levels of the $B_{2}$ fraction of the crude protein of the angola grass, tifton- 85 grass, limpo grass, tanner grass, nilo grass and aleman grass were 0.35 ; $0.36 ; 0.37 ; 0.45 ; 0.46$ and 0.54 percent units, respectively. The general average for the setaria grass was $15.74 \%$.

By examining the interaction of grasses and cutting age, there were significant differences among grasses. On the $14^{\text {th }}$ day, the levels of the $B_{2}$ fraction of crude protein of the nilo grass and angola grass presented the smallest values.

Ribeiro et al. (1998) reported levels of 31.34; 30.37 and $28.78 \%$ of $B_{2}$ in the crude protein at 28,42 , and 56 days of re-growth, respectively, for tifton-85 hay, which were larger than the observed ones in this work, at the same cutting ages (5.85; 14.35 and 19.87\%). Malafaia et al. (1997) found $26.95 \%$ for tifton-85 at 60 days of age, which was larger than the estimated value (20.28\%) calculated by the regression equation (Table 5).

Henriques et al. (2007b) evaluated nilo grass, angola grass, limpo grass and setaria grass in the northern Rio de Janeiro state and found larger values for the $B_{1}+B_{2}$ fractions at 56 days of age for the setaria and limpo grasses, and at 28 days of age for angola grass and nilo grass .

The level of $B_{3}$ fraction of the crude protein differed among cutting age and there was an interaction among grasses and cutting ages $(\mathrm{P}<0.01)$. The levels of the $\mathrm{B}_{3}$ fraction of the aleman grass and tifton- 85 grass showed a quadratic behavior in function of the cutting age (Table 5), while the nilo grass, tanner grass, angola grass and setaria grass showed a linear decrease. The equations for linear and quadratic regression of the limpo grass were not significant. The maximum levels for the $\mathrm{B}_{3}$ fraction of the crude protein for the aleman grass and tifton- 85 grass were estimated on the $6^{\text {th }}$ and $23^{\text {rd }}$ days, equal to 56.27 and $58.86 \%$, respectively. Angola grass, setaria grass, nilo grass and tanner grass showed daily decreases of $0.33 ; 0.44$,
0.79 and 0.63 percent unities, respectively. The general average for the limpo grass was of $32.86 \%$.

Ribeiro et al. (1998) found for the $B_{3}$ fraction of the crude protein in tifton- 85 hay at 28,42 and 56 days of age, levels of 35.73; 35.02 and $29.01 \%$, respectively, which were lower than the values obtained in the present work at 28 and 42 days of age (44.60 and $35.31 \%$, respectively) and higher than those found at 56 days of age (26.93\%). Malafaia et al. (1997) reported a level of 26.95\% for tifton85 at 60 days of age, which was higher than the value estimated by the regression equation for this grass in the present work (21.63\%).

The level of $\mathrm{C}$ fraction corresponds to the acid detergent insoluble protein, considered to be no degradable in the rumen and indigestible in the intestines. This fraction was influenced only by the forage species $(\mathrm{P}<0.01)$ and it was observed a quadratic behavior for the tanner grass and a linear decrease for the angola grass, in function of the cutting age while for the others grasses, the regression equations were not significant (Table 6). The maximum level of the $C$ fraction in tanner grass (29.52\%) was estimated at 31 days of age and the daily decrease in limpo grass was of 0.41 percent units.

Limpo grass showed the highest level of the $\mathrm{C}$ fraction of crude protein on the $14^{\text {th }}$ day. On the $28^{\text {th }}$ day, the level in the limpo grass was higher than those of aleman grass, nilo grass, angola grass, setaria grass and tifton-85 grass. On the $42^{\text {nd }}$ and $56^{\text {th }}$ days, the level of the limpo grass was larger than in nilo grass.

Gonçalves et al. (2003) reported increases in the C fraction of the crude protein of Tifton 85 hay at the cutting ages of 28, 42, 63 and 84 days, varying from 17.4 to $22.8 \%$. Similarly, the $\mathrm{B}_{3}$ fraction of the crude protein increased and $\mathrm{B}_{2}$ presented little variation, according to the increase of the cutting age.

Ribeiro et al. (1998) found levels of the protein C fraction of tifton- 85 hay on the $28^{\text {th }}, 42^{\text {nd }}$ and $56^{\text {th }}$ days of $5.74 ; 6.76$ and $6.44 \%$, respectively, which were smaller than the values obtained in this work on the $28^{\text {th }}, 42^{\text {nd }}$ and $56^{\text {th }}$ days (20.13; 21.80 and 22.19\%, respectively). However, Malafaia \& Vieira (1997) reported level of $16.95 \%$ for tifton85 at 60 days of age.

Most of the studied grasses showed a linear increase in the levels of total carbohydrates, non structural carbohydrates and in the level of the $A+B_{1}$ fraction of the carbohydrates in function of the cutting age. The $\mathrm{B}_{2}$ fraction of the carbohydrates presented a quadratic behavior for the aleman grass, angola grass, setaria grass and tifton-85 grass. The $\mathrm{C}$ fraction of the carbohydrates showed a linear 
Table 6 - Levels of the fraction C (\% CP) of the grasses and the respective regression equations in relation to the cutting age (x, in days)

\begin{tabular}{|c|c|c|c|c|c|c|c|c|}
\hline \multirow[t]{2}{*}{ Grass } & \multicolumn{4}{|c|}{ Cutting ages (days) } & & \multirow[t]{2}{*}{ Equation $^{1}$} & \multirow[t]{2}{*}{$r^{2}$} & \multirow[t]{2}{*}{$\mathrm{P}$ value } \\
\hline & $14 * *$ & $28 * *$ & $42 *$ & $56 * *$ & Mean & & & \\
\hline Aleman grass & $15.28 b$ & $21.31 b$ & $21.44 \mathrm{ab}$ & $25.00 \mathrm{ab}$ & 20.76 & $\hat{y}=y=20.76$ & - & $\mathrm{P}>0.05$ \\
\hline Nilo grass & $14.66 b$ & $19.06 b$ & $12.82 b$ & $11.90 \mathrm{~b}$ & 14.61 & $\hat{y}=y=14.61$ & - & $\mathrm{P}>0.05$ \\
\hline Tanner grass & $23.70 b$ & $31.36 \mathrm{ab}$ & $25.66 \mathrm{ab}$ & $19.96 \mathrm{ab}$ & 25.17 & $\hat{y}=12.69+1.07 x^{n s}-0.0170 x^{2 *}$ & 0.27 & - \\
\hline Angola grass & $22.19 b$ & 19.99b & $17.75 \mathrm{ab}$ & 19.18ab & 19.77 & $\hat{y}=y=19.78$ & - & $\mathrm{P}>0.05$ \\
\hline Limpo grass & $46.76 a$ & $47.52 \mathrm{a}$ & $30.95 a$ & 33.03a & 39.57 & $\hat{y}=54.00-0.41 x^{* *}$ & 0.37 & - \\
\hline Setaria grass & $12.47 \mathrm{~b}$ & $17.38 b$ & $19.06 \mathrm{ab}$ & $19.47 a b$ & 17.09 & $\hat{y}=y=17.09$ & - & $\mathrm{P}>0.05$ \\
\hline Tifton-85 grass & $16.81 b$ & $20.13 b$ & $21.80 \mathrm{ab}$ & $22.19 \mathrm{ab}$ & 20.23 & $\hat{y}=y=20.23$ & - & $\mathrm{P}>0.05$ \\
\hline
\end{tabular}

Means followed by the same letter, in the same column do not differ by Tukey's test. Significant at $1 \%(* *)$ and $5 \%(*)$ of probability and $\mathrm{ns}=$ non significant $(\mathrm{P}>0.05)$.

1 y in \% dry matter.

behavior for the tifton-85 and no significant differences for the others grasses.

The average levels of the fraction $\mathrm{B}_{1}$ of the crude protein (\% CP) varied from 8.42 to $5.06 \%$. Considering that the degradation rate of the $\mathrm{B}_{1}$ fraction is in the range from 100 to $350 \% / \mathrm{h}$, the lower its percentage, fewer losses of nitrogen can occur in the rumen. However, the average level of the $\mathrm{B}_{2}$ fraction (\% CP) was in the range from 15.74 to $7.36 \%$. This fraction is composed by structural carbohydrates that are effectively degraded in the rumen, with a rate of degradation varying from 8 to 15\%/h, therefore, as larger its content, the higher will be the microbial growth, provided there is an available source of protein and appropriate amounts of it. In this research, the level of the $B_{2}$ fraction of crude protein was relatively low. The best values found by Gonçalves et al. (2001) for this fraction of crude protein were at 21 days of age. However, the $B_{2}$ fraction of crude protein was not affected by the cutting age.

The $\mathrm{B}_{3}$ fraction of crude protein (\% CP) varied from 42.98 to $32.86 \%$. The rate of degradation of the $B_{3}$ fraction is in the range from 0.08 to $1.3 \%$, and it could be degraded in the rumen, but it is mainly supplying amino acids for the small intestine.

The level of the $\mathrm{C}$ fraction of the crude protein (\% CP) varied from 39.57 to $14.61 \%$. This fraction is composed by nitrogenous compounds associated to the lignin fraction (acid detergent insoluble protein) and because it is resistant to the attack of the microbial enzymes and of the host it could not be absorbed along the digestive tract.

Limpo grass presented the smallest levels of nonprotein nitrogenous compounds and larger levels of the acid detergent insoluble nitrogen fraction (\% CP) and of C fraction of carbohydrates (\% total carbohydrates), in relation to the others grasses, and high percentage of neutral detergent insoluble nitrogen as reported by Lima et al. (1999) and Newman et al. (2002). The largest levels of $B_{2}$ fraction of the total carbohydrates and of crude protein were observed at 42 and 56 days of age.
For crude protein, setaria grass had an average level of crude protein of $14.23 \%$ and the levels of $B_{2}$ and $B_{3}$ fractions equal to 15.74 and $39.38 \%$ of the crude protein, respectively. This represents a good protein contribution for ruminal fermentation and for the amino acids absorption in the small intestine. The others grasses presented similar values for $A, B_{1}, B_{2}, B_{3}$ and $C$ fractions of the crude protein, emphasizing that the levels of the $C$ fraction were even larger for nilo grass and setaria grass.

The purpose of evaluating the proteins and carbohydrates fractions for their appropriate characterization is to look for the maximization of the efficiency of growth of the ruminal microorganisms (Russell et al., 1992). The levels of the carbohydrates fractions and nitrogenous compounds of the foods together with the parameters of kinetics of ruminal degradation supply more adequate information on the nutritional value of the foods than only the chemical composition values.

\section{Conclusions}

Among the studied grasses, setaria is the one that has the best chances to be used by the animal. Their levels of $B_{2}$ fractions of the total carbohydrates, and $B_{2}$ and $B_{3}$ fractions of the crude protein are high, what makes it possible the maximum income and the rate of growth of the ruminal microorganisms, as well as a high exit of protein of the $\mathrm{B}_{3}$ fraction for absorption in the intestine. Nilo grass and angola grass also would be very well used by the animal, in a similar way to the setaria grass, but with larger protein contribution for the intestine. Limpo grass is the least suitable due to its high levels of $\mathrm{C}$ fraction (carbohydrates and protein). For selection of an ideal forage, not only the proportion of the digestible fractions of the carbohydrates should be considered but also the biomass production per unit of area, a factor that is intimately related to the cutting age. 


\section{References}

AGRICULTURAL AND FOOD RESEARCH COUNCIL - AFRC. Energy and protein requirements of ruminants. Wallingford: CAB International, 1993. 159p.

AKIN D.E.; BURDICK, D. Percentage of tissue types in tropical and temperate grass leaf blades and degradation of tissues by rumen microorganisDM. Crop Science, v.15, p.661-668, 1975.

AKIN, D.E. Histological and physical factors affecting digestibility of forages. Agronomy Journal, v.81, p.17-25, 1989.

FOX, D.G.; TEDESCHI, L.O.; TYLUTKI, T.P. The net carbohydrate and protein system for evaluating herd nutrition and nutrient excretion. Animal Feed Science and Technology, v.112, p.29-78, 2004.

GILL, M.; BEEVER, D.E.; FRANCE, J. Biochemical bases needed for the mathematical representation of whole animal metabolism. Nutrition Research Reviews, v.2, n.1, p.181-200, 1989.

GONÇALVES, G.D.; SANTOS, G.T.; JOBIM, C.C. et al. Determinação do consumo, digetibilidade e frações protéicas e de carbohydrates do feno de tifton 85 em diferentes idades de corte. Revista Brasileira de Zootecnia, v.32, n.4, p.804-813, 2003.

GONÇALVES, G.D.; SANTOS, G.T.; JOBIM, C.C. et al. Determinação das frações de proteína e de carbohydrates de Grasss do gênero Cynodon em idades ao corte. Acta Scientiarum, v.23, n.4, p.789-794, 2001.

HALL, M.B. Methodological challenges in carbohydrate analyses. Revista Brasileira de Zootecnia, v.36, p.359-367, 2007 (supl.).

HENRIQUES, L.T.; COELHO DA SILVA, J.F.; DETMANN, E. et al. Frações de carbohydrates de quatro Grasss tropicais em diferentes idades de corte e doses de adubação nitrogenada. Arquivo Brasileiro de Medicina Veterinária e Zootecnia, v.59, n.3, p.730-739, 2007a.

HENRIQUES, L.T.; COELHO DA SILVA, J.F.; DETMANN, E. et al. Frações dos compostos nitrogenados de quatro Grasss tropicais em diferentes idades de corte e doses de adubação nitrogenada. Arquivo Brasileiro de Medicina Veterinária e Zootecnia, v.59, n.3, p.740-748, 2007b.

JUNG, H.G.; ALLEN, M.S. Characteristics of plant cell wall affecting intake and digestibility of forages by ruminants. Journal of Animal Science, v.73, n.9, p.2774-2790, 1995.

KRISHNAMOORTHY, U.; SNIFFEN, C.J.; STERN, M.D. et al. Evaluation of a mathematical model of rumen digestion and an in vitro simulation of rumen proteolysis to estimate the rumenundegraded nitrogen content of feedstuffs. British Journal of Nutrition, v.50, n.3, p.55-568, 1983.

LACERDA, P.D.; MALAFAIA, P.A.M.; VIEIRA, R.A.M. et al. Variação anual da composição bromatológica de duas forages cultivadas nas baixadas litorâneas do estado do Rio de Janeiro, Brasil. Ciência Rural, v.34, n.2, p.523-529, 2004.

LICITRA, G.; HERNANDEZ, T.M.; VAN SOEST, P.J. Standardization of procedures for nitrogen fractionation of ruminant feeds. Animal Feed Science Technology, v.57, n.4, p.347-358, 1996.

LIMA, G.F.C.; SOLLENBERGER, L.E.; MOORE, J.E. et al. Concentração e fracionamento do nitrogênio em grass forages tropicais e subtropicais. In: REUNIÃO ANUAL DA SOCIEDADE BRASILEIRA DE ZOOTECNIA, 36., 1999, Brasília. Anais... Brasília: Sociedade Brasileira de Zootecnia, 1999. p.115-117.

MALAFAIA, P.A.M.; VIEIRA, R.A.M. Técnicas de determinação e avaliação dos compostos nitrogenados em alimentos para ruminantes. In: TEIXEIRA, J.C. (Ed) Digestibilidade em ruminantes. Lavras, 1997. p.29-54.

MALAFAIA, P.A.M.; VALADARES FILHO, S.C.; COELHO DA SILVA, J.F. et al. Determinação das frações que constituem os carbohydrates totais de alguns volumosos e concentrados. In: REUNIÃO ANUAL DA SOCIEDADE BRASILEIRA DE ZOOTECNiA, 33., 1996, Fortaleza. Anais... Fortaleza: Sociedade Brasileira de Zootecnia, 1996. p.306-308.

MALAFAIA, P.A.M.; VALADARES FILHO, S.C.; VIEIRA, R.A.M. et al. Determinação e cinética ruminal das frações protéicas de alguns alimentos para ruminantes. Revista Brasileira de Zootecnia, v.26, n.6, p.1243-1251, 1997.

MERTENS, D.R. Kinetics of cell wall digestion and passage in ruminants. In: JUNG, H.G., BUXTON, D.R.; HATFIELD, R.D. et al. (Eds.) Forage cell wall structure and digestibility. Madison: American Society of Agronomy, 1993. p.535-570.

NATIONAL RESEARCH COUNCIL - NRC. Nutrient requirements of beef cattle. 7.ed. rev. Washington, D.C.: National Academy Press, 2001. 381p.

NEWMAN, Y.C.; SOLLENBERGER, L.E.; KUNKLE, W.E. et al. Crude protein fractionation and degradation parameters of limpograss herbage. Agronomy Journal, v.94, p.1381-1386, 2002.

NOCEK, J.; RUSSEL, J.B. Protein and carbohydrate as an integrating system. Relationship of ruminal availability to microbial contribution and milk production. Journal Dairy Science, v.71, n.5, p.2070-2075, 1998.

RIBEIRO, K.G.; PEREIRA, O.G.; VALADARES FILHO, S.C. et al. Determinação das frações que constituem a crude protein e os carbohydrates totais do feno de tifton-85. In: REUNIÃO ANUAL DA SOCIEDADE BRASILEIRA DE ZOOTECNIA, 35. 1998, Botucatu. Anais... Botucatu: Sociedade Brasileira de Zootecnia, 1998. p.122-124.

ROSA, B.; OLIVEIRA, L.E.M.; ROCHA, G.P. Crescimento do capim-angola (Brachiaria mutica) em função da densidade das plantas e idades de corte. Pesquisa Agropecuária Tropical, v.29, n.2, p.157-163, 1999.

RUSSEL, J.B.; O'CONNOR, J.D.; FOX, D.G. et al. A net carbohydrate and protein system for evaluating cattle diets: I. Ruminal fermentation. Journal of Animal Science, v.70, n.11, p.3551-3561, 1992.

UNIVERSIDADE FEDERAL DE VIÇOSA - UFV. SAEG (Sistemas para Análises Estatísticas e Genéticas) versão 8.0 - Manual de instruções. Viçosa, MG: CPD/UFV, Divisão de Pesquisa e Desenvolvimento, 2000. 142p.

SILVA, D.J.; QUEIROZ, A.C. Análise de alimentos - métodos químicos e biológicos. 3.ed. Viçosa, MG, UFV: Imprensa Universitária, 2004. 235p.

SNIFFEN, C.J.; O’CONNOR, J.D.; VAN SOEST, P.J. et al. A net carbohydrate and protein system for evaluating cattle diets: II. Carbohydrate and protein availability. Journal of Animal Science, v.70, n.11, p.3562-3577, 1992.

TOKARNIA, C.H.; CHAGAS, B.R.; CHAGAS, A. D. et al. Anemia hemolítica causada por Ditaxis desertorum (Euphorbiaceae) em bovinos. Pesquisa Veterinária Brasileira. v.17, n.3, p.112-116, 1997.

VALERIO, J.R. Percevejo-das-Grass: Blissus leucopterus ou Blissus antillus. Campo Grande: Embrapa Gado de Corte, 2000. 3p. (Circular Técnica, 43).

VAN SOEST, P.J. Nutritional ecology of the ruminant. New York, 1994. 476p.

VIEIRA, R.A.M.; PEREIRA, J.C.; MALAFAIA, P.A.M. et al. Fracionamento dos carbohydrates e cinética de degradação in vitro da Neutral detergent fiber da extrusa de bovinos a pasto. Revista Brasileira de Zootecnia, v.29, n.3, p.889-897, 2000.

WILSON, J.R. Influence of temperature and nitrogen on growth, photosynthesis and accumulation of non-structural carbohydrates in a tropical grass, Panicum maximum var.trichoglume. Netherlands Journal of Agricultural Science, v.23, n.2, p.48-61, 1975. 